\title{
Some Aspects of Criminal Liability FOR SPORTS INJURIES
}

\author{
Bronislava Coufalová, Jan Pinkava ${ }^{1}$
}

\section{Faculty of Law, Palacký University Olomouc, Czech Republic email: bronislava.coufalova@upol.cz, jan.pinkava@upol.cz}

COUFALOVÁ, Bronislava - Pinkava, Jan. Some Aspects of Criminal Liability for Sports Injuries. International and Comparative Law Review, 2014, Vol. 14, No. 2, pp. 59-69. DOI: 10.1515/iclr-2016-0051.

\begin{abstract}
The essence of the problem of using criminal law to affect sports injuries caused in sport lies in the fact that the means of criminal law to interfere in sport or not. From this perspective, we talk about two theories: the theory of absolute immunity sports and the theory of strict adherence to the rule of law. These two concepts are supplemented by a number of theories that perspective as an autonomous system that contains its own rules of conduct that regulate internal relations in sports. In the event that disciplinary liability is not sufficient in this case, can be applied liable under civil and administrative law. In the most serious cases, the possibility of protecting the rights and legitimate interests in sport according to the norms of criminal law. The subject of this article is selected aspects of criminal responsibility in different sports, both individual and collective. From individual sports we mainly deal with skiing. The contact sports in this article will be football, hockey and rugby.
\end{abstract}

Keywords: criminal liability, injuries in sport, disciplinary liability, team sports, individual sports, violation of the rules, illegal conduct

\section{Introduction to liability for injuries of sportsmen}

It is a very difficult question how to use criminal law to affect sports injuries caused in sport. This question has not been clearly resolved. The essence of the problem lies in the fact that the means of criminal law to interfere in sport or not. From this perspective, we talk sometimes about so called theory of absolute immunity sports, which is the antithesis of the theory of strict adherence to the rule of law. The theory of absolute immunity sport ${ }^{2}$ is based on the fact that the sport is so autonomous activity that is hardly possible in this system in any way regulate the relations from outside. It is a sphere of social activity that creates its

1 Department of Criminal Law, Faculty of Law, Palacký University in Olomouc, Czech Republic. This article was elaborated under the project IGA - SPP 917100238/31 - Criminal liability in sports environment.

2 PRUSÁK, Jozef. Šport a právo (Úvod do dejín, teórie a praxe právej zodpovednosti $v$ športe). Bratislava: Šport, slovenské telovýchovné vydavateĺstvo, 1984, p. 10.; KRÁLÍK, Michal. Právo ve sportu. 1st edition. Praha: C.H. Beck, 2001. p. 2 and p. 106 and following 
own rules of behavior, and ability to adequately and independently punish violations. The theory of strict (rigid) application of the law in the area of sport ${ }^{3}$ is the antithesis of the theory of absolute immunity sport and means that will lead to the application of legal liability, including criminal liability in the sport in the same way as happens in other social activities. This means that any relations arising in the operation of the sport will be addressed through the rule of law, rather than internal regulations. These two concepts are supplemented by a number of theories that contain modifications of these concepts. It is therefore a certain combination of internal regulatory systems and sports law.

Sport can be understood from this perspective as an autonomous system that contains its own rules of conduct that regulate internal relations in sports. These rules are internal in nature and therefore must be in accordance with the laws of the country, or with the international treaties and other documents. Individual sports branches also have their own sports authorities, which are set up to resolve disputes within the certain sport branch. This is essentially a disciplinary or arbitration body of the relevant sports industry.

In the event that disciplinary liability is not sufficient in this case, can be applied liability according to the civil and administrative law. In the most serious cases, there is the possibility of protecting the rights and legitimate interests in sport according to the norms of criminal law.

The complexity of the issue contributes to the diversity of sport as a kind of social activity, when there are so many sports activities of different nature, which may constitute criminal liability. An important criterion for judging will be cultural factors (resp. sports and cultural), traditions of a country, sports and legal theory applied in a particular country, legislation in force, settled case-law, conventions, customary ways of considering the cases, sports policy, sports ethics, good manners, active sports legislation and many other factors.

The subject of this article are the aspects of criminal responsibility in different sports, both individual and collective. In individual sports the main interest will be relating to skiing. The contact sports contains mainly football, hockey and rugby. Although these are only some selected sports, it can be stated that the basic theory and mechanisms of accountability may in part be used in many other individual and collective sports.

\section{Individual sports}

Individual sport is a type of sport in which injury is rarely caused to sportsmen by any other sportsmen. It is primarily due to the very nature of these kinds of sporting activities, where their essence is not direct physical contact with other sportsmen, but the execution just an individual sport activity of specific

3 Srov. PRUSÁK, Jozef. Šport a právo (Úvod do dejín, teórie a praxe právej zodpovednosti $v$ športe). Bratislava: Šport, slovenské telovýchovné vydavateĺstvo, 1984, p. 10-11 
character. Thus injuries occur rather due to different kinds of failures sportsmen when either intentionally or negligently fails to comply with safety regulations, the rules of a sport or game, the usual degree of caution, general prevention duties, or different kinds of rules and regulations of not binding character, but which govern execution certain activities. These cases are, however, in most cases, establishing disciplinary liability, any civil (damages the injured person, etc.), administrative or criminal liability there could mean unreasonably harsh punishment. Among individual sports include various kinds of contact, respectively combat sports, which, however, because of their special character in this article will not described.

\section{Skiing}

The main individual sport in which injury can be caused is skiing, which can quite often cause injury to others as a result of the unlawful behavior of other sportsmen (in the broad sense, including for example snowboard).

In the Czech case law, it is primarily about the decision of Supreme Court No. 8 Tdo 68/2010, concerning criminal liability for skiers bodily harm to another person as a result of failure to comply with the general prevention duties in skiing. In this case there was a serious injury of under-age skier due to carelessness and negligent conduct by another skier. Skier during his ride on the slope stroke down her, and as a result of this collision were several injuries, mainly faces significant injury, abdominal and chest injury. Specifically, splenic rupture, leading to operation and to eliminate, namely severe major organ with a period of 8 weeks of treatment and permanent consequences of reducing the body's defenses. Skier was found criminally responsible for the crime of bodily harm under $\$ 146$ par. 1 of the Criminal Code. Legal sentence of that decision sets general rules for determining liability skiers when the skier is required, inter alia, to adapt speed and driving their skills and experience and the overall situation on the ground, which passes through (especially terrain, snow and weather conditions, prospective conditions, the number and movement other skiers or other persons, etc.) to allow him on time and at a sufficient distance to react to unexpected obstacle driving.

The decision is interesting in terms of determining criminal responsibility in two directions. First, it is a reference to the so-called infringement of general preventive obligations under $\$ 415$ of the Law no. 40/1964. (Civil Code) and by reference to the rules of conduct for skiers, issued by the International Ski Federation.

The obligation to comply with the rules of the International Ski Federation is also based on another Supreme Court decision No. 25 Cdo 1506/2004 concerning civil liability. That decision inter alia sets that the rules of the International Ski Federation skiing, although are not generally binding legal regulation, but for skiers on the slope are binding and are obliged to follow them. If it does not and 
there is a breach of these rules, there will be a breach of the general prevention duties, and such conduct may rise to civil liability.

An important factor in assessing criminal liability for skiers will be the question of contributory negligence of the injured party or other persons on the slope. During the evidence remains to be demonstrated whether the damaged party has complied with all the rules of the sport, not violating the general obligation of prevention, therefore if somehow contributed to injury.

Foreign case law is considerably richer and contains a number of decisions concerning criminal responsibility in sport. One of the example is the case in People Hall ${ }^{4}$. It concerned the death of a skier as a result of the injuries caused by another skier. The accused in this case failed to adapt fast ride on skies and hit the slopes in damaged in such a way that it caused a number of head injuries and brain injuries. The injured was taken to hospital, but attempts at resuscitation were unsuccessful, and as a result of these injuries died. On that basis, the accused was charged with killing another skier. The accused was eventually found guilty by the Supreme Court of the State of Colorado of negligent homicide and sentenced to a custodial sentence of 90 days, to 240 hours of community service and three years of supervision of probation officer.

\section{Team sports (collective sports)}

Team sports are kinds of sports in which many sports injuries are caused due to the actions of other sportsmen. It is type of group sports with higher risk of the possibility of injuries caused by the sportsmen among themselves than in individual sports. The main reason is especially frequent physical contact between sportsmen during sports games, although it is not a primary goal of this game (as opposed to a group of combat sports, where physical contact involving attacking one sportsman to another is essence of the combat sport). For this reason, risk of injury appears, which differs according to the type and nature of the sport.

During the sport there are numerous minor injuries, which are part of the sport itself and there is no need to apply nor disciplinary liability. Sometimes, however, there is a more serious nature of the injury, which is caused by one of the sportsman as a result of the unlawful conduct of another sportsman. In such cases, it is worth considering the application of disciplinary responsibility, thus punishment by the disciplinary bodies. In serious cases where there is a breach of fundamental social values and relationships that are protected by the criminal law may also be applied criminal liability.

Although still part of society sees the application of criminal responsibility in sport rather skeptically, we must realize that in extreme cases is this sanction necessary. We are not talking here about the criminal liability for any injury

4 People v Hall. In: FindLaw [online]. Colorado, 2000 [cit. 2014-01-26]. Available on: http:// caselaw.findlaw.com/co-supreme-court/1009399.html 
caused by sportsmen as a result of acts of another person, but only the most serious cases where the criminal law acts as "ultima ratio" with the principle of subsidiarity of criminal repression.

\section{Football}

The first team sport, which will be covered in this chapter is the football. Football belongs among the most common sports where injury to players is caused. However, it should be noted that some of these injuries are caused by carelessness and due to normal sports competitions, regardless of fault opponent. However, there is also existence of injuries which are caused players to each other. These injuries will be sufficient in most cases to solve by using the liability under disciplinary matters, but according to the principle of subsidiarity of criminal repression will be in extreme and most serious cases also apply criminal liability.

Among the Czech cases, very important is the Supreme Court's decision No. 3 Tdo 1355/2006, which relates to criminal liability for health damage as a result of a wrongful act of another player. The subject of this proceeding was causing injury to one another during a football championship game in football. The accused during the battle of the ball caused in this case the injured fracture of the fibula and torn deltoid ligament at the inner left ankle which required hospitalization and nearly two-month sick leave. The district court found the defendant guilty of the offense of bodily harm under $\$ 224$ paragraph. 1 of the Criminal Law (Old Criminal Law, according to the effective Penal Code is a $\$ 146$ par. 1), while there was a remission of sentence and referral damaged entitled for damages to the proceedings in civil cases.

The applicant argued that the courts consider the question of objectively site wrong because he did not commit willful or negligent act in such form, as required by the Criminal Code. His action was among the so-called classic slipway, which are quite numerous in football, he did not consider his action as a rare excess, based on which it would be necessary to infer criminal liability. At the same time the accused did not deny that there has been a violation of the rules of sport, but argued that it was not a serious non-standard violation that would constitute legal responsibility (among others argued that he was awarded a yellow card, which proves that it was a surgery usual, nothing uninspired, if it were some kind of excess, it should be awarded a red card). The argument of the defendant is interesting in that part, that in the case of team sports could be considered as permission damaged justification.

These arguments are followed by the Supreme Court, which stated that the purpose of the rules of sport is not only guarantee a fair hearing in the sport, but also to protect the life and health of the players against such behavior, which often lead to inflicting injury. There is social interest about violation of social rules, and therefore it must be sanctioned.

\section{(C) Palacký University Olomouc, Czech Republic, 2014. ISSN 1213-8770 (print), ISSN: 2464-6601 (online).}


Another case, which relates to liability for injuries caused by an opponent during a football match, is the decision of the District Court in Blansko No. 77 C 353/2009. Although it is a civil decision, it should be noted with regard to the issue precisely because it can be used as a test case for cases excluding criminal responsibility.

Between the plaintiff and defendant occurred during a football match to a contact when the defendant tripped plaintiff by skimming from the side and caused him by such conduct compound fracture of the tibia left leg. Slip occurred at a time when the plaintiff and the defendant held the ball while running toward him, slipped on the wet field, thereby causing him this injury. The applicant had to be immediately hospitalized and underwent surgery to the legs and subsequent rehabilitation. As a result, he became incapable of work for about 5 months.

The plaintiff in that decision, argued that there was a violation of the rules of the game (as evidenced by the red card by the referee of the match) and at the same time been violated general prevention obligation laid down in civil law, under which each act so as to avoid damage health. The defendant pleaded the contrary, it could be unlawful act, because the slip occurred independently of his will, due to wet grass. Based on these facts, the civil court decided that the defendant has infringed prevention duties and set rules of the game.

In foreign case law we can mention several other cases involving criminal liability for injuries caused in football. Except when there is an injury caused as a result of careless play a violation committed by one player may also recall a situation where there is a willful infliction of injury due to a short circuit. One of the foreign cases of this nature is for example R Davies ${ }^{5}$. In this football match there was a conflict between two players when digging a free kick when one of the players went to the second and hit him in the face, which caused him a fractured cheekbone. It was in this case a deliberate attack against the integrity of the opponent, which resulted in injury to a second footballers. The accused was not only disciplinary punishment, he was immediately expelled from the game, but on the basis of this behavior he was in subsequent criminal proceedings given a prison sentence of six months imprisonment. These cases of criminal responsibility are distinguished from cases where there is cause personal injury as a result of negligent conduct, which consisted in violation of the rules, but that occurred in the heat of battle. If one player injures another in football duel, it does not automatically exclude criminal responsibility, however, when considering the amount and type of punishment is necessary to take these circumstances into account.

5 Decision R v Davies, available at GARDINER, Simon a kol. Sports Law. 3rd edition. United Kingdom: Cavendish, 2006, p. 599 
Another in a series of cases is $\mathrm{R} \mathrm{McHugh}^{6}$, which concerned a situation where the accused with damaged during an amateur soccer match vie for the ball during the headers fight, while damaged after this encounter fell to the ground. The accused intentionally kicked him in the face, causing him serious injuries. On the basis of this meeting was the accused sentenced to punishable by imprisonment for three years.

A specific example was the football match of the Irish Football League in $2000^{7}$, when the youthful intentionally hit an opponent during a football match, which died after the strike. During the investigation it was found that the strike caused damage to one artery and subsequent bleeding into the brain, which led to this unexpected death. The juvenile was first accused of murder, the indictment was reclassified as homicide offense, because it was demonstrated that the strike was conducted intentionally, but the death was due to unfortunate coincidences (it was stated that the chances of such an injury is one in a million).

Another interesting model case of criminal responsibility is the case of $\mathrm{R}$ Blissett $^{8}$ (1992). During this match was a duel for the ball when the two players clashed heads when flirting kick, resulting in one of the players suffered a fractured cheekbone and eye injuries. As a result of this injury had damaged terminate his sports career. The accused was charged with the offense of bodily injury, which occurred as a result of violent behavior during the game. In his favor spoke the President of Football Association, which inter alia mentioned that it was a contact that occurs many times in the match, for this reason, did not make anything unusual. The accused was eventually acquitted and had not been imposed no penalty.

Relatively rare are cases where during sporting activities resulted in death due to illegal conduct of any of the sportsmen. One such example is the foreign case of R Moore'. In this case there was a situation where the accused jump knees crashed into the victim and hit him on the outgoing goalkeeper, who at that moment also went into battle knees first. The injured was caused internal injuries as a result of which a few days later he died. The judge who decided the case, said that the main criterion is whether there has been a breach of the rules of football or not. Football is legally allowed game, but the players are obliged both with a degree of caution in order not otherwise suffered bodily harm. However, using such force that it may be another consequence of those actions caused the death, then they may be criminally responsible for the killing.

6 Decision R McHugh, available at COX, Neville, SCHUSTER, Alex, COSTELLO Cathryn. Sport and the Law. 1st edition. Dublin: First Law, 2004, p. 185

7 COX, Neville, SCHUSTER, Alex, COSTELLO Cathryn. Sport and the Law. 1st edition. Dublin: First Law, 2004, p. 185-186

8 Decision R Blissett, available at GARDINER, Simon a kol. Sports Law. 3rd edition. United Kingdom: Cavendish, 2006, p. 601

9 Decision R v Moore, available at GARDINER, Simon a kol. Sports Law. 3rd edition. United Kingdom: Cavendish, 2006, p. 602 
An interesting case of criminal responsibility related to fights during a sporting event is a case in Butcher Jessop ${ }^{10}$. In this case, there was a scuffle between three professional soccer players during a match Glasgow Rangers and Glasgow Celtic in the Scottish Football League matches. This struggle between these players occurred before the part that was reserved for supporters of Celtic Glasgow. Although in this case there were no injuries of anyone player, this brawl has resulted in adverse reactions. The rivalry between fans of the two clubs is well known and long-term problem. For this reason, sparked a brawl between football players upheaval, just because it supported the animosity that exists between the two camps. On the basis of these events was one of the players convicted of an offense in relation to a breach of public order.

Fights, disorderly conduct and public order offenses are not in some soccer spectators unusual. However, this case is interesting for the reason that these acts have been committed by players of football clubs, and during the match. In terms of criminal prosecution is also necessary except elements of the offense also take into account the environment in which the conduct is committed, socio-political conditions and other factors. It should be borne in mind that in the case of this type of malicious behavior will be taken into account where the acts were committed. Some countries, respectively cities are famous for rivalry between fans of the local football club, which borders on fanaticism, while in other countries the problem may not even exist ${ }^{11}$. Often plays an important role different religious beliefs among the fans of the two clubs, for this reason it is very undesirable to encourage any conflict. Should this incident occurred in the Czech conditions, we would stress only disciplinary action, rather than the application of criminal law.

Finally, it should be noted that the above findings that relate to football, will not be used for example in hockey, where the brawl during a match is almost normal part of the sport and is almost decriminalized.

\section{Ice hockey}

Ice hockey is considered as one of a series of sports, which commonly occurs, causing injury, possibly to a greater extent than other team sports. Since this is a very contact sport, injuries constitute an essential part of the sport, for this reason it is necessary to apply criminal responsibility very sensitively. To clarify this issue, we introduce several situations that contribute to better clarify the issue.

From the Czech cases may be mentioned decision, which relates to the issue of criminal responsibility in sport, the Supreme Court decision No. 5 Tdo

10 Decision Butcher v Jessop, available at GARDINER, Simon a kol. Sports Law. 3rd edition. United Kingdom: Cavendish, 2006, p. 598

11 Examples of countries where problems are frequently found among football fans, we can mention Turkey - Istanbul (rivalry between local clubs Galatasaray and Fenerbahce), followed by Poland, Russia, Italy, etc 
997/2002. The decision concerns the case in which the accused hockey player in ice hockey match mileage deliberately hit the tip of the stick in the face striker of second team, while at the time of this meeting has tampered with the puck, it was therefore beyond a certain "passion play". The injured party has suffered health consisting of a contusion of the upper lip, breaking several teeth crowns and squeezed with the duration of treatment for at least 14 days. On the basis of this meeting has been accused by the district court found guilty of the crime of assault and was sentenced to a fine.

In connection with the injury can mention a few foreign cases involving criminal liability for injuries caused by another player. In the case of $\mathrm{R}$ v Ciccarelli ${ }^{12}$ was a situation, when it was mentioned hockey player struck him on the rail during the game after being signaled offside. The injured had not managed to stop and hit the accused on the boards, he responded by taking it three times struck in the head with the stick. The accused was sentenced to a fine and punishable by imprisonment for one day.

Other similar cases were, for example attack of boston's attacker McSorley on Donald Breshear (it was also the blow stick at the moment opponent did not have the puck and the attack did not predicted, for that conduct accused was convicted for assault of weapons to 18 months imprisonment conditionally), further Bertuzzi case where the attacker hit him back of the head and down it on ice in such a manner that the damaged unprotected face fell onto ice and subsequently lost consciousness while he result of this shock and collapse was caused several fractures per head. Bertuzzi was found guilty and sentenced to an imprisonment conditionally and a fine of half a million dollars.

Specific issue from the perspective of criminal liability for injuries in hockey is the question of so-called "fights" between two players. These cases are known especially in the NHL, where fights are considered an essential part of hockey and complement the atmosphere of the sport. These fights between players are punished only in terms of disciplinary punishments, for this reason it is so far avoided criminal liability. However, recently started talking about whether these scuffles between players not to ban or at least somehow not limiting ${ }^{13}$. This reflection on the limitations of these fights are due to several injuries which in recent years has been in the $\mathrm{NHL}^{14}$.

12 Decision R v Ciccarelli, available at GARDINER, Simon a kol. Sports Law. 3rd edition. United Kingdom: Cavendish, 2006, p. 610

13 As is in NHL generally regular, every club has dedicated a player, provocateur, which focuses on the opponent's best players in an attempt to provoke a miserable them during the game. If there is a fight, both players will receive disciplinary punishment right on the ice, which is in terms of the absence of key players who were involved in a fight purposefully awkward situation.

14 For example fight from October 2013 between player of Montreal Georg Parros and his rival Colton Orrel from Toronto. In this fight Parros fell face down on the ice and remaind limp. Although this injury seemed to be very serious, Parros suffered only concussion. 


\section{Rugby, American football}

Rugby and American football are among other sports, for which there is frequent contact, respectively contact between players in these sports is an integral part. For this reason, the possibilities of using criminal responsibility are minimal. The Czech case is unaware of any case that would cover these sports, for that reason, we will try to briefly outline these issues on foreign model cases.

In the case of $\mathrm{R} v$ Gingell ${ }^{15}$ had been actioned when during rugby matches one of several players struck the other (who at the time was on the ground) in the face, which caused him a fractured cheekbone, nose and jaw. The defendant pleaded guilty to this even though such conduct was somehow provoked, does not deprive the accused of criminal liability for the act committed. On the basis of these facts, he was sentenced to imprisonment for six months, which was subsequently reduced to two months.

The second similar case was $\mathrm{R} v$ Moss $^{16}$, when the accused deliberately damaged struck in the face out of the fight for the ball, causing him to fracture of any bone in the eye which required surgery. The accused was sentenced to eight months imprisonment.

The third similar case is $\mathrm{R} v$ Calton ${ }^{17}$, in which during school match the youthful deliberately kicked the other player, who at the time was on the ground. Given the fact that this attack is made on the cheek and jaw breaking of the opponent, the accused was sentenced to 12 months in a detention facility for juveniles (this sentence was eventually reduced to 3 months).

In the case of $\mathrm{R} v$ Lloyd ${ }^{18}$ accused intentionally kicked damaged in the face, which caused him a fractured cheekbone and other painful injuries. The court in this case found that match rugby is not environment for committing such violations and sentenced the accused to imprisonment for 18 months.

\section{Conclusion}

Application of criminal law in the area of sport is the subject of ongoing discussions. Its proponents and opponents are based on two basic theories that have to be seen as the last resort of the issue. On one hand it must be considered that sport is autonomous system and has its own rules of behavior, but also it should be appreciated that this may not be adequate in certain situations. In these cases,

15 Decision R v Gingell, available at GARDINER, Simon a kol. Sports Law. 3rd edition. United Kingdom: Cavendish, 2006, p. 600

16 Decision R v Moss, available at GARDINER, Simon a kol. Sports Law. 3rd edition. United Kingdom: Cavendish, 2006, p. 601

17 Decision R v Calton, available at GARDINER, Simon a kol. Sports Law. 3rd edition. United Kingdom: Cavendish, 2006, p. 601

18 R v Lloyd, avaliable at LEWIS, Adam, TAYLOR, Jonathan. Sport: Law and Practice. 2nd edition. Haywards Heath: Bloomsbury Professional, 2008, p. 1088 
the legislation in force, respectively standards of individual branches of law will regulate undesirable behavior more effectively. Criminal law in this situation will act as so-called ultima ratio, the application of its standards will occur only at the moment when the standards of other branches of the law are not able to protect social relations, interests and values sufficiently. This assertion is supported by the decision-making of the courts, although in the Czech Republic this is not numerous, but it can also build on knowledge from abroad. Finally, it can therefore be concluded that current of thought advocating full autonomy of sport in terms exclude the possibility of regulating this area by legal system, is currently already surpassed. On the other hand, it is necessary to respect the fact that each sport is to some extent governed by its own rules, which also produces. 